\title{
PENILAIAN RADIOLOGIS EFLUEN PUSAT SAINS DAN TEKNOLOGI AKSELERATOR (PSTA) KE SISTEM BIOTA DENGAN ERICA TOOL
}

\section{RADIOLOGICAL ASSESSMENT OF EFFLUENT OF CENTER FOR ACELERATOR SCIENCE AND TECHNOLOGY TO THE BIOTIC SYSTEM USING ERICA TOOL}

\author{
Adinda Tisha Desviana ${ }^{1}$, Gede Sutresna Wijaya ${ }^{2}$ \\ ${ }^{1}$ Departemen Teknik Nuklir dan Teknik Fisika, Fakultas Teknik, Universitas Gadjah Mada, Jalan Grafika No. 2, Yogyakarta \\ ${ }^{2}$ Pusat Sains dan Teknologi Akselerator BATAN, Jalan Babarsari, Kotak Pos 6101 ykbb, Yogyakarta \\ adinda.tisha.d@mail.ugm.ac.id
}

Diterima 5 Desember 2017, diterima dalam bentuk perbaikan 16 Januari 2018, disetujui 26 Februari 2018

\begin{abstract}
ABSTRAK
PENILAIAN RADIOLOGIS EFLUEN PUSAT SAINS DAN TEKNOLOGI AKSELERATOR (PSTA) KE SISTEM BIOTA DENGAN ERICA TOOL. Salah satu konsekuensi dari beroperasinya Reaktor Kartini adalah limbah dari aktivitas pada fasilitas tersebut. Limbah cair adalah salah satu dari beberapa limbah yang dihasilkan dari beroperasinya reaktor. Limbah cair pada saluran terpadu reaktor harus dikelola dengan baik karena meskipun sangat kecil, dimungkinkan ada kontaminan baik itu zat kimia ataupun zat radioaktif. Zat radioaktif yang terlepas ke badan air melalui efluen berpotensi bercampur dengan sumber air yang dimanfaatkan oleh masyarakat untuk irigasi dan perikanan, serta mencemari habitat bermacam-macam organisme. Pencegahan terhadap lepasan radionuklida dilakukan dengan cara melakukan pemantauan lingkungan. Sampel yang diambil di antaranya adalah sampel air dan sedimen. Selain itu, dilakukan prediksi dosis serap yang diterima oleh biota non-manusia menggunakan perangkat lunak ERICA Tool. Tujuan penelitian ini adalah untuk menganalisis apakah dosis yang diterima biota jika terdapat lepasan masih berada di bawah rentang baku yang diizinkan oleh Peraturan Kepala BAPETEN Nomor 7 Tahun 2013. Dari hasil penelitian diperoleh bahwa di sampel air terkandung radionuklida alami $212 \mathrm{~Pb},{ }^{214} \mathrm{~Pb},{ }^{228} \mathrm{Ac},{ }^{212} \mathrm{Bi}$, dan ${ }^{214} \mathrm{Bi}$. Di dalam sampel sedimen terdapat kandungan radionuklida alami ${ }^{212} \mathrm{~Pb},{ }^{214} \mathrm{~Pb},{ }^{228} \mathrm{Ac},{ }^{212} \mathrm{Bi}$, ${ }^{214} \mathrm{Bi}$, dan radionuklida ${ }^{137} \mathrm{Cs}$ yang konsentrasi aktivitasnya dihitung menggunakan ERICA Tool diperoleh sebesar 1,10 $\times 10^{-3} \mathrm{~Bq} / \mathrm{jam}$. Konsentrasi ${ }^{137} \mathrm{C}$ s yang terukur ini masih jauh di bawah batas yang diizinkan BAPETEN yaitu sebesar 5,1 × 103 Bq/jam sehingga masih aman untuk biota.
\end{abstract}

Kata kunci : Efluen, ERICA Tool, dosis serap biota

\section{ABSTRACT}

RADIOLOGICAL ASSESSMENT OF EFFLUENT OF CENTER FOR ACCELERATOR SCIENCE AND TECHNOLOGY TO THE BIOTIC SYSTEM USING ERICA TOOL. One of the consequences of the Kartini Reactor operation is its waste. The liquid waste is one type of the several wastes from the reactor. The liquid waste in the integrated canal must be well managed because there is a probability of the emerging contaminant product, either as a chemical substance or radioactive substance regardless of the small amount. The radioactive substance released to the environment as the effluent flowing to the small river may be used as the water source for irrigation and fishery, and also as a habitat to various organisms. The prevention towards the radionuclides release is done by taking sample as the step of monitoring environment. The samples taken were water and sediment. Furthermore, the dose absorption received by non-human biota was predicted using ERICA Tool software. The purpose of dose predictionusing ERICA Tool was to determine the dose received by non-human biota is still under permissible limit value based on BAPETEN Chairman Regulation Number 7 year 2013. The water samples contained natural radionuclides ${ }^{212} \mathrm{~Pb},{ }^{214} \mathrm{~Pb},{ }^{228} \mathrm{Ac},{ }^{212} \mathrm{Bi},{ }^{214} \mathrm{Bi}$, and ${ }^{40} \mathrm{~K}$. The sediment samples contained natural radionuclides ${ }^{212} \mathrm{~Pb},{ }^{214} \mathrm{~Pb}$, ${ }^{228} \mathrm{Ac},{ }^{212} \mathrm{Bi},{ }^{214} \mathrm{Bi},{ }^{40} \mathrm{~K}$ and ${ }^{137} \mathrm{Cs}$. The activity of ${ }^{137} \mathrm{Cs}$ dose absorption is also calculation result using ERICA Tool was $1.10 \times 10^{-3} \mathrm{~Bq} /$ hour. The activity of ${ }^{137} \mathrm{Cs}$ measured was under permissible limit value of BAPETEN Chairman Regulation $5.1 \times 10^{3} \mathrm{~Bq} /$ hour, so it was considerably safe for non-human biota.

Keywords : Effluent, ERICA Tool, biotic dose absorption 


\section{PENDAHULUAN}

ingkungan yang dihuni oleh manusia dikelilingi oleh radiasi pengion yang didominasi oleh radiasi alami.

-Aktivitas manusia dapat meningkatkan tingkat radiasi baik karena memanfaatkan sumber radionuklida alami maupun karena memproduksi radionuklida buatan [1]. Fasilitas nuklir di suatu daerah dapat menyebabkan kenaikan paparan radiasi terhadap makhluk hidup yang ada di sekitarnya. Selain itu, keberadaan fasilitas tersebut memungkinkan terjadinya lepasan radionuklida.

Radionuklida yang terlepas ke lingkungan dapat menyebar melalui rantai makanan dan menyebabkan efek deterministik dan efek stokastik. Salah satu bagian dari lingkungan yang berpotensi tercemar oleh lepasan radionuklida berupa efluen cair yaitu badan air yang terletak di sekitar Reaktor Kartini. Badan air tersebut mengalir ke permukiman penduduk sekitar dan berpotensi menjadi sumber air yang dimanfaatkan oleh masyarakat untuk irigasi dan perikanan serta merupakan habitat bermacam-macam organisme.

Pengendalian terhadap lepasnya radionuklida produk fisi merupakan tindakan proteksi radiasi terhadap masyarakat dan lingkungan di sekitar fasilitas reaktor. Identifikasi pencemaran lingkungan oleh radionuklida harus dilakukan sejak awal agar efek yang ditimbulkan sedikit mungkin sesuai dengan prinsip ALARA (As Low as Reasonably Achievable).

Pada beberapa kasus, transfer radionuklida kelingkungan harus dimodelkan karena data pengukuran yang tidak lengkap[1]. Salah satu perangkat lunak yang sudah diakui oleh IAEA untuk menghitung tingkat dosis yang diserap oleh biota non-manusia adalah ERICA Tool. ERICA Tool merupakan sistem perangkat lunak yang fleksibel dan terkomputerisasi yang memiliki struktur berdasarkan ERICA Integrated Approach untuk menilai risiko radiologi pada biota [2]. Penggunaan ERICA Tool untuk melakukan penilaian radiologi sudah dilakukan oleh banyak peneliti, antara lainterhadap biota air tawar di Finlandia [3], kandungan tritium pada remis laut [4], penilaian radiologi pada situs tambang di Asia Tengah [5], dan penilaian radiologi pada gumuk pasir di daerah pantai Drigg [6].

Perhitungan dosis serap biota menggunakan perangkat lunak ERICA Tool melalui langkah-langkah seperti pada Gambar 1 [7].

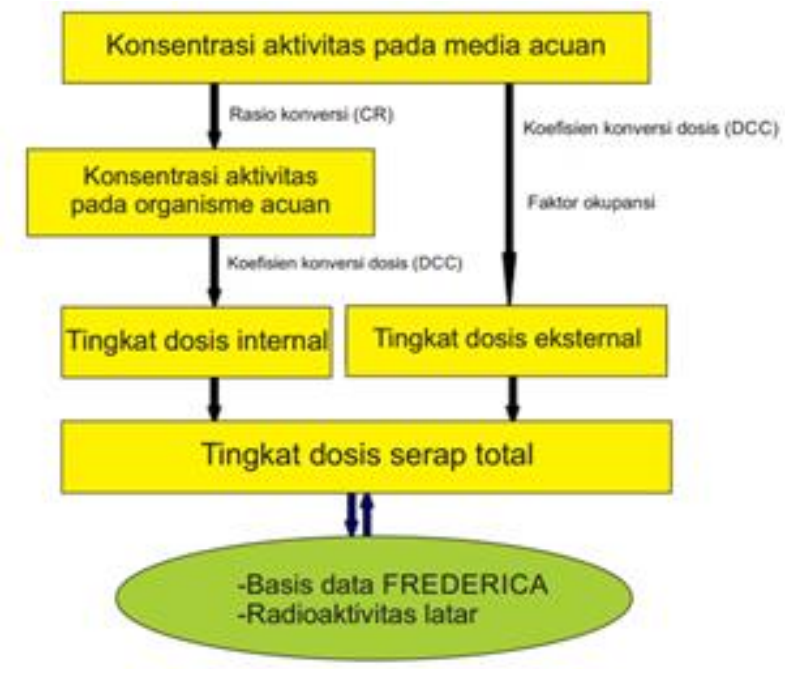

Gambar 1. Proses perhitungan dosis serap biota menggunakan ERICA Tool [7]

\section{METODOLOGI}

\section{Alat}

Alat sampling yang digunakan dalam penelitian ini meliputi gayung untuk mengambil dan memasukkan sampel air dari lokasi pengambilan ke jirigen ukuran $20 \mathrm{~L}$ serta kantung plastik untuk wadah sampel sedimen di lokasi pengambilan sebelum di preparasi di laboratorium. 
Pada tahap preparasi sampel air dibutuhkan cawan porselin kapasitas $2 \mathrm{~L}$ dan kompor listrik dengan daya 600 watt untuk menguapkan sampel air. Preparasi sampel sedimen membutuhkan nampan untuk menjemur sampel di bawah sinar matahari, kemudian menggunakan ballmill untuk menggerus sampel sedimen dan menjadikannya homogen. Sampel sedimen juga perlu di ayak hingga lolos butir $75 \mu \mathrm{m}$ dan diukur beratnya dengan timbangan.

Tahap analisis secara kuantitatif dan kualitatif radionuklida yang terdapat dalam sampel air dan sedimen dilakukan dengan spektrometri gamma dengan detector Ortec $\mathrm{HpGe}$ yang mempunyai efficiency relatif $20 \%$ terhadap NalTI 3 × 3 inch dan dilengkapi dengan perangkat lunak Genie 2000 dari Canberra. Hasil analisis secara kuantitatif dijadikan inputan pada perangkat lunak ERICA Tool, untuk mengetahui dampak radiologis beberapa biota akuatik dari konsentrasi aktivitas radionuklida yang terdapat pada air dan sedimen.

\section{Bahan}

Sampel air sejumlah 20 liter diambil dari lokasi badan air sebelum kolam pembuangan terpadu (sampel A) yang di anggap sebagai lokasi hulu atau belum tercampur dengan air lepasan dari sistem saluran terpadu, lokasi kolam pembuangan terpadu sebagai titik lepasan (sampel B), dan lokasi badan air setelah kolam pembuangan terpadu yang merupakan bagian hilir dari (sampel $\mathrm{C}$ ), dimana dimungkinkan telah terjadi pencampuran dari sampel dari lokasi A (hulu) dan B (lepasan kolam terpadu). Sampel sedimen masing-masing sebanyak \pm 500 gram diambil dari ketiga lokasi pengambilan sampel air secara representative sehingga dapat mewakili setiap lokasi A, B dan C. Material standar IAEA Soil 6, untuk kalibrasi effisiensi detektor $\mathrm{HpGe}$, agar diperoleh effisiensi fungsi geometri yang sesuai antara material standar dan sampel sedimen, yang diambil dari lokasi A, B dan C.

\section{Cara kerja}

Pengambilan sampel air dan sedimen, dilakukan pada tiga lokasi A, B dan C. Lokasi A adalah daerah di bagian hulu dari kolam PSTA, dimana pada lokasi ini sampel air dan sedimen dipastikan tidak dipengaruhi oleh air lepasan dari PSTA. Lokasi B adalah kolam akhir sistem saluran buangan terpadu PSTA. Efluen yang dilepaskan oleh PSTA ke lingkungan berasal dari kolam akhir ini. Ada 4 buah kolam kecil yang terhubung satu dengan yang lain dengan satu titik lepasan ke badan air atau sungai kecil yang ada di dekatnya sampel yang berasal dari ke empat kolam di beri kode B-1, B-2, B-3 dan B-4. Lokasi C adalah lokasi di daerah hilir dari titik lepasan dari kolam akhir sistem saluran terpadu. Pada lokasi $\mathrm{C}$ ini dimungkinkan akan ada proses pencampuran dari air yang berasal dari hulu kolam dengan air lepasan kolam (Lokasi B).

Preparasi sampel air dan sampel sedimen, dilakukan dengan cara:. sampel air sebanyak $20 \mathrm{~L}$ dituang ke dalam cawan porselin ukuran $2 \mathrm{~L}$ secara bertahap untuk diuapkan di atas kompor listrik secara perlahan (tidak sampai mendidih untuk menghindari terjadinya gelembung) sampai diperoleh sisa hasil penguapan sekitar 100 $\mathrm{mL}$ sampel air. Sisa hasil penguapan sekitar $100 \mathrm{~mL}$ dimasukkan ke dalam vial polietilen dan didiamkan selama 4 minggu dalam keadaan tertutup rapat. Sampel sedimen yang berasal dari lokasi A, B dan C dijemur di bawah sinar matahari sampai kering ( \pm 5 hari), kemudian dihaluskan dengan ballmill selama 10 menit dengan kecepatan putar $200 \mathrm{rpm}$. Sampel sedimen kemudian dilewatkan pada ayakan dengan ukuran lolos butir $75 \mu \mathrm{m}$, dimasukkan ke dalam vial berbentuk silinder ukuran $100 \mathrm{~mL}$ sampai penuh, kemudian ditimbang berat sampelnya dan didiamkan selama 4 minggu dalam vial tertutup rapat dan di seal, sehingga dapat dipastikan tidak ada gas/udara yang keluar dari vial.

Setelah 4 minggu sampel air dan sedimen dari masing-masing lokasi pengambilan dicacah selama 15 jam menggunakan detektor HPGe satu persatu. Analisis radionuklida secara kualitatif dan kuantitatif terhadap hasil pencacahan sampel air dan sampel sedimen menggunakan perangkat lunak Genie 2000 Canberra. Analisis kuantitatif berupa aktivitas radionuklida dijadikan data masukan untuk perhitungan dosis serap biota menggunakan perangkat lunak ERICA Tool.

Simulasi dilakukan dengan menggunakan beberapa skenario, misalnya skenario terburuk dengan mensimulasikan seluruh radionuklida yang berpotensi lepas dari reaktor riset (24 isotop), semua dengan konsentrasi lepasan sesuai nilai batas lepasan (NBL) sesuai Perka bapeten No 7/2013. Juga simulasi apabila seluruh (24) isotop lepas ke badan air dengan tingkat konsentrasi $100 \%, 75 \%, 50 \%, 25 \%, 10 \%, 5 \%$ dan $1 \%$ dari NBL. Simulasi juga dilakukan apabila kondisi lepasan radionuklida produk fisi konsentrasinya $50.000,80.000$ sampai 100.000 kali dari konsentrasi yang terukur. Kemudian dilakukan simulasi apabila isotop produk fisi yang 
terukur, debitnya $1 / 10,1 / 25,1 / 50,1 / 90$ dan $1 / 100$ dari debit semula, bagaimana dampak radiologinya pada biota di badan air.

\section{HASIL DAN PEMBAHASAN}

Berdasarkan analisis sampel dengan spektrometri gamma, radionuklida yang ditemukan pada ketiga lokasi pengambilan sampel air yaitu di hulu, pada titik lepasan dan di hilir badan air (Lokasi A, B dan C) adalah radionuklida yang terjadi secara alamiah, yaitu radionuklida ${ }^{212} \mathrm{~Pb},{ }^{214} \mathrm{~Pb},{ }^{228} \mathrm{Ac},{ }^{212} \mathrm{Bi},{ }^{214} \mathrm{Bi}$, dan ${ }^{40} \mathrm{~K}$ yang berasal dari anak luruh radionuklida deret uranium, torium dan radionuklida yang bukan merupakan deret yaitu radionuklida potasium. Tidak ada radionuklida produk fisi yang tercacah pada sampel air dari ketiga lokasi pengambilan sampel. Adapun radionuklida yang terkandung di dalam sampel sedimen pada lokasi pengambilan A (lokasi badan air di hulu titik lepasan) dan lokasi C (lokasi di hilir titik lepasan efluen) melalui analisis dengan spektrometri gamma adalah radionuklida ${ }^{228} \mathrm{Ac},{ }^{212} \mathrm{Bi},{ }^{214} \mathrm{Bi},{ }^{212} \mathrm{~Pb},{ }^{214} \mathrm{~Pb}$, dan ${ }^{40} \mathrm{~K}$. Pada sampel sedimen di lokasi titik lepasan efluen atau lokasi kolam terpadu B, dari ke empat kolam terdapat ${ }^{137} \mathrm{Cs}$ yang merupakan radionuklida produk fisi. Kemungkinan adanya ${ }^{137} \mathrm{Cs}$ pada sampel sedimen B (lokasi kolam) adalah karena sedimen terdeposisi dalam jangka waktu yang lama pada kolam pembuangan terpadu. Cesium-137 yang terdapat di kolam pembuangan terpadu diperkirakan berasal dari laboratorium penelitian, karena air buangan yang terdapat pada kolam terpadu berasal dari saluran yang menghubungkan laboratorium-laboratorium penelitian yang mungkin merupakan sisa hasil cucian alat lewat bak cuci yang dialirkan ke bak penampung untuk dikelola dengan jalan pemipaan yang dibantu pompa [8].

Sebelum dilakukan perhitungan aktivitas radionuklida, terlebih dahulu dibuat kurva kalibrasi efisiensi menggunakan sumber standar Soil 6. Dari kurva kalibrasi efisiensi didapatkan persamaan $y=0,0004 e^{-0,002 x}$ dengan nilai $R^{2}=0,9906$.

Sebelum dianalisis, seluruh sampel air dan sedimen pada penelitian ini terlebih dahulu didiamkan selama kurang lebih 1 bulan agar kesetimbangan sekuler antara radionuklida induk dan radionuklida anak tercapai. Sampel didiamkan dalam keadaan tertutup untuk memastikan bahwa tidak ada ${ }^{222 R n}$ yang keluar dari wadah sampel berbentuk silinder, sehingga sistem kesetimbangan sekuler antara radionuklida induk dalam hal ini uranium, torium dan radionuklida anak luruhnya tidak terganggu [9]. Efisiensi sistem spektrometri gamma ditentukan dari material standar IAEA soil 6 yang juga diperlakukan sama dengan sampel yang dianalisis. Bentuk geometri antara wadah sampel sedimen dan wadah material standar menggunakan wadah dengan dimensi yang sama, karena effisiensi sistem spektrometri gamma sangat dipengaruhi oleh bentuk geometri, misalnya diameter sampel, tinggi dan komposisi kimia serta densitas sampel [10].

Dengan menggunakan perangkat lunak SPSS windows versi 10, dilakukan uji-t pada sampel air dan sampel sedimen. Uji-t dilakukan pada sampel $A$ terhadap $B$, dan sampel $A$ terhadap sampel $C$. Dalam uji ini $H_{0}$ adalah rata-rata perbedaan dari kedua sampel adalah nol, sedangkan $\mathrm{H}_{1}$-nya adalah terdapat angka rata-rata perbedaan. Uji-t dilakukan dengan tingkat kepercayaan sebesar 95\%.

Tabel 1. Hasil uji-t pada sampel air dan sampel sedimen

\begin{tabular}{lc}
\hline Jenis sampel & Hasil uji-t \\
\hline Air A dan B & 0,884 \\
Air A dan C & 0,993 \\
Sedimen A dan B & 0,071 \\
Sedimen A dan C & 0,484 \\
\hline
\end{tabular}

Berdasarkan uji-t yang dilakukan terhadap seluruh sampel, dapat disimpulkan bahwa $\mathrm{H}_{0}$ diterima dan $\mathrm{H}_{1}$ ditolak untuk semua pengujian sampel, yaitu $\mathrm{H}_{0}$ lebih besar dari 0,05.

Penentuan aktivitas ${ }^{226} \mathrm{Ra}$ menggunakan sistem spektrometri gamma secara langsung dapat dilakukan pada energi 186,211 keV. Tetapi, karena yield energinya sangat kecil yaitu 3,64\% dan adanya kontribusi cacah dari ${ }^{235} \mathrm{U}$ pada energi 185,7 keV maka pengukurannya tidak dapat diandalkan. Oleh karena itu, dilakukan metode 
pengukuran yang lebih sensitif dan akurat menggunakan energi gamma dari ${ }^{214} \mathrm{~Pb}$ dan ${ }^{214} \mathrm{Bi}$ dengan menunggu sampai terjadi kesetimbangan sekuler antara ${ }^{226} \mathrm{Ra}$ dan ${ }^{222 R n}$ [10], [11].

Radionuklida ${ }^{137} \mathrm{Cs}$ juga dihitung aktivitasnya karena ${ }^{137} \mathrm{Cs}$ merupakan radionuklida produk fisi yang terdapat pada sampel dari kolam terpadu B-1, B-2, B-3, dan B-4. Aktivitas ${ }^{137}$ Cs terlarut yaitu sebesar $1,10 \times 10^{-}$ ${ }^{3} \mathrm{~Bq} / \mathrm{jam}$. Batas lepasan ${ }^{137} \mathrm{Cs}$ di badan air menurut Peraturan Kepala BAPETEN Nomor 7 Tahun 2013 yaitu sebesar $5,1 \times 10^{3} \mathrm{~Bq} / \mathrm{jam}$,sedangkan konsentrasi ${ }^{137} \mathrm{Cs}$ terlarut adalah sebesar $1,10 \times 10^{-3} \mathrm{~Bq} / \mathrm{jam}$. Dari hasil perhitungan, konsentrasi ${ }^{137} \mathrm{Cs}$ jauh berada di bawah batas lepasan yang telah ditetapkan oleh BAPETEN.

Dalam melakukan simulasi pada ERICA Tool, ada beberapa skenario yang dibuat. Terdapat dua jenis simulasi yang dilakukan. Simulasi jenis pertama yaitu simulasi dengan data masukan riil yang terukur pada sampel, sedangkan simulasi jenis kedua merupakan simulasi yang bersifat skenario. Ditentukan beberapa skenario dalam rangka mengetahui parameter apa yang lebih berpengaruh terhadap angka dosis serap biota. Skenario yang pertama yaitu diasumsikan jika terdapat lepasan radionuklida produk fisi ke badan air sesuai ambang batas yang ditetapkan oleh BAPETEN. Skenario yang kedua yaitu variasi terhadap debit efluen. Skenario ketiga yaitu variasi terhadap konsentrasi ${ }^{137} \mathrm{Cs}$ yang berhasil diukur. Skenario keempat yaitu variasi terhadap jumlah radionuklida.

Simulasi dengan masukan data riil dilakukan dengan memasukkan data aktivitas radionuklida terukur pada sampel air dan sampel sedimen. Aktivitas radionuklida yang menjadi masukan yaitu ${ }^{212} \mathrm{~Pb}$ dan ${ }^{214} \mathrm{~Pb}$ untuk sampel A dan C serta penambahan aktivitas dari ${ }^{137} \mathrm{C}$ untuk sampel B. Aktivitas radionuklida ${ }^{212} \mathrm{Bi}$, ${ }^{214} \mathrm{Bi}$, dan ${ }^{228} \mathrm{Ac}$ tidak menjadi masukan karena tidak terdapat data $\mathrm{K}_{\mathrm{d}}$ radionuklida tersebut pada basis data ERICA Tool. Hasil simulasi pada Tabel 2 memperlihatkan bahwa dosis yang diterima oleh biota dengan aktivitas radionuklida alami yang terukur masih dalam batas aman menurut IAEA.

Tabel 2. Hasil perhitungan dosis dengan data masukan aktivitas ${ }^{212} \mathrm{~Pb}$ dan ${ }^{214} \mathrm{~Pb}$

\begin{tabular}{lccc}
\hline \multirow{2}{*}{ Biota } & \multicolumn{3}{c}{ Dosis Serap Biota $(\mu$ Gy/jam $)$} \\
\cline { 2 - 4 } & $\mathrm{A}$ & $\mathrm{B}$ & $\mathrm{C}$ \\
\hline Fitoplankton & 1,26 & 16,98 & 2,16 \\
Zooplankton & 6,47 & 87,32 & 11,13 \\
Crustacea & 6,67 & 88,22 & 4,35 \\
Molusca gastropoda & 4,76 & 62,81 & 8,18 \\
Molusca bivalvia & 4,75 & 62,86 & 8,17 \\
Amfibi & 0,00 & 0,06 & 0,08 \\
Larva Serangga & 6,85 & 89,04 & 11,58 \\
Tumbuhan berpembuluh & 0,42 & 3,97 & 0,71 \\
\hline
\end{tabular}

Untuk mengetahui apakah radionuklida ${ }^{137} \mathrm{Cs}$ yang terkandung di dalam sampel sedimen dari lokasi $\mathrm{B}$ akan memberikan dampak radiologi pada biota, maka dilakukan simulasi keadaan sebenarnya dengan masukan konsentrasi aktivitas ${ }^{137} \mathrm{Cs}$ yang diukur. Berdasarkan sampel sedimen yang diambil dari kolam pembuangan terpadu, keempat sampel mengandung radionuklida ${ }^{137} \mathrm{Cs}$ sebesar $1,10 \times 10^{-3} \mathrm{Bg} / \mathrm{jam}$ atau $6,81 \times 10^{-5} \mathrm{~Bq} / \mathrm{L}$. Hasil simulasi dengan ${ }^{137} \mathrm{Cs}$ yang terukur dapat dilihat pada Tabel 3. Pada Tabel 3 dapat disimpulkan bahwa konsentrasi aktivitas ${ }^{137} \mathrm{C}$ s sebesar $1,10 \times 10^{-3} \mathrm{~Bq} / \mathrm{jam}$ tidak akan membahayakan biota yang berada di badan air PSTA, karena dosis serap yang diterima biota masih jauh di bawah batas aman ( $<400 \mu \mathrm{Gy} / \mathrm{jam}$ ).

Skenario pertama yaitu keadaan yang diasumsikan terdapat lepasan sejumlah radionuklida produk fisi yang berpotensi terlepas ke badan air sesuai ambang batas yang ditetapkan oleh BAPETEN. Radionuklida yang disimulasikan adalah radionuklida produk fisi yang berpotensi terlepas dari reaktor riset dengan nilai batas lepasan (NBL) sesuai Perka BAPETEN No 7/2013, yaitu untuk 24 radionuklida di antaranya ${ }^{51} \mathrm{Cr}\left(1,6 \times 10^{7}\right),{ }^{54} \mathrm{Mn}$ $\left(6,3 \times 10^{5}\right),{ }^{58} \mathrm{Co}\left(4,5 \times 10^{5}\right),{ }^{60} \mathrm{Co}\left(6,0 \times 10^{4}\right),{ }^{65} \mathrm{Zn}\left(8,1 \times 10^{4}\right),{ }^{95} \mathrm{Zr}\left(5,9 \times 10^{5}\right),{ }^{95} \mathrm{Nb}\left(2,7 \times 10^{5}\right),{ }^{103} \mathrm{Ru}\left(7,5 \times 10^{6}\right),{ }^{106} \mathrm{Ru}$ $\left(8,7 \times 10^{5}\right),{ }^{110 \mathrm{~m}} \mathrm{Ag}\left(1,5 \times 10^{6}\right),{ }^{124} \mathrm{Sb}\left(7,1 \times 10^{6}\right),{ }^{125} \mathrm{Sb}\left(1,8 \times 10^{6}\right),{ }^{131} \mathrm{I}\left(1,3 \times 10^{5}\right),{ }^{134} \mathrm{Cs}\left(3,5 \times 10^{4}\right),{ }^{137} \mathrm{Cs}\left(5,1 \times 10^{3}\right),{ }^{141} \mathrm{Ce}$ $\left(4,0 \times 10^{6}\right)$, ${ }^{144} \mathrm{Ce}\left(4,4 \times 10^{5}\right),{ }^{89} \mathrm{Sr}\left(8,1 \times 10^{5}\right),{ }^{90} \mathrm{Sr}\left(1,9 \times 10^{5}\right),{ }^{234 \mathrm{U}}\left(3,6 \times 10^{5}\right),{ }^{238} \mathrm{Pu}\left(5,9 \times 10^{4}\right),{ }^{239} \mathrm{Pu}$ dan ${ }^{240} \mathrm{Pu}$ $\left(5,4 \times 10^{4}\right),{ }^{241} \mathrm{Am}\left(6,6 \times 10^{4}\right) \mathrm{Bq} / \mathrm{jam}$. 
Tabel 3. Hasil perhitungan dosis dengan masukan konsentrasi aktivitas ${ }^{137} \mathrm{Cs}$ terukur

\begin{tabular}{lcc}
\hline Biota & $\begin{array}{l}\text { Dosis Serap Biota } \\
(\mu \text { Gy/jam })\end{array}$ & $\begin{array}{c}\text { Hasil simulasi dengan } \\
\text { masukan batas BAPETEN }\end{array}$ \\
\hline Fitoplankton & $6,76 \times 10^{-7}$ & $5,96 \times 10^{-4}$ \\
Zooplankton & $4,91 \times 10^{-7}$ & $8,21 \times 10^{-4}$ \\
Crustacea & $1,78 \times 10^{-3}$ & 2,16 \\
Mollusca Gastropoda & $1,58 \times 10^{-3}$ & 1,91 \\
Mollusca Bivalvia & $1,48 \times 10^{-3}$ & 1,80 \\
Amfibi & $4,04 \times 10^{-5}$ & 0,05 \\
Larva Serangga & $3,54 \times 10^{-3}$ & 4,30 \\
Tumbuhan berpembuluh & $1,77 \times 10^{-3}$ & 2,15 \\
\hline
\end{tabular}

Simulasi dilakukan menggunakan penilaian tingkat 2 (tier 2) dengan nilai $K_{d}, \mathrm{CR}$, dan faktor okupansi sesuai data yang ada pada basis data ERICA Tool. Pada simulasi digunakan penilaian tingkat 2 karena dengan penilaian tingkat 1 tidak didapatkan data keluaran berupa dosis serap biota. Oleh karena penilaian tingkat 3 tidak bersifat menentukan apakah dosis serap yang diterima biota berbahaya atau tidak, maka penilaian yang paling tepat digunakan pada penelitian ini adalah penilaian tingkat 2. Batas dosis serap biota adalah $400 \mu \mathrm{Gy} / \mathrm{jam}$ untuk fitoplankton, zooplankton, Crustacea, Mollusca Gastropoda, Mollusca Bivalvia, larva serangga, dan tumbuhan berpembuluh, serta $40 \mu$ Gy/jam untuk amfibi sesuai dengan yang telah ditetapkan oleh IAEA pada tahun 1992, USDOE pada tahun 2002, dan UNSCEAR pada tahun 1996. Hasil simulasi skenario pertama dapat dilihat pada Tabel 4.

Tabel 4. Hasil simulasi dengan variasi aktivitas radionuklida

\begin{tabular}{lccccccc}
\hline Biota & \multicolumn{7}{c}{ Dosis Serap Biota yang diterima $(\mu \mathrm{G} y / j \mathrm{jam})$} \\
\cline { 2 - 8 } Persen dari NBL & $100 \%$ & $75 \%$ & $50 \%$ & $25 \%$ & $10 \%$ & $5 \%$ & $1 \%$ \\
\hline Fitoplankton & 602,68 & 451,83 & 301,21 & 150,62 & 60,27 & 30,12 & 6,03 \\
Zooplankton & 170,62 & 127,97 & 85,35 & 42,68 & 17,06 & 1,70 & 1,71 \\
Crustacea & $6.430,66$ & $4.818,95$ & $3.219,99$ & $1.607,21$ & 643,07 & 322 & 64,31 \\
Mollusca Gastropoda & $6.014,98$ & $4.506,91$ & $3.011,92$ & $1.503,49$ & 601,50 & 301,19 & 60,15 \\
Mollusca Bivalvia & $5.578,96$ & $4.179,99$ & $2.793,57$ & $1.394,53$ & 557,90 & 279,36 & 55,79 \\
Amfibi & 604,46 & 453,38 & 302,24 & 151,15 & 60,45 & 30,22 & 6,04 \\
Larva Serangga & 12.177 & $9.124,37$ & $6.097,78$ & $3.043,05$ & $1.217,70$ & 609,78 & 121,77 \\
Tumbuhan berpembuluh & $6.052,74$ & $4.535,17$ & $3.030,81$ & $1.512,59$ & 605,27 & 303,08 & 60,53 \\
\hline
\end{tabular}

Pada Tabel 4, warna merah menunjukkan bahwa yang dosis serap biota telah melampaui batas aman. Warna kuning menunjukkan bahwa terdapat potensi masalah namun batas dosis serap belum terlampaui. Warna hijau menunjukkan dosis serap biota masih jauh di bawah batas dosis serap yang ditetapkan. Pada Tabel 4 dapat dilihat pula bahwa jika kondisi terburuk terjadi, maka terdapat beberapa biota yang mendapatkan dosis serap melampaui batas yaitu fitoplankton, Crustacea, Mollusca Gastropoda, Mollusca Bivalvia, amfibi, larva serangga, dan tumbuhan berpembuluh; sedangkan untuk zooplankton masih tetap berada di bawah batas dosis serap.

Dosis serap Crustacea, Mollusca Gastropoda, Mollusca Bivalvia, amfibi dan tumbuhan berpembuluh masih melampaui batas yang ditentukan hingga aktivitas konsentrasi dari 24 radionuklida yang berpotensi lepas dari reaktor riset radionuklidanya sebesar $10 \%$ dari nilai batas lepasan yang ditetapkan oleh BAPETEN. Bahkan 
pada larva serangga dosis serapnya masih berwarna merah (indikasi melampaui batas aman) hingga aktivitas konsentrasi radionuklidanya $5 \%$ dari NBL. Jika pada saat seluruh radionuklida yang disimulasikan terdapat pada efluen, maka dosis serap akan dikatakan aman untuk semua jenis biota jika besarnya konsentrasi lepasan adalah $1 \%$ dari nilai batas lepasan BAPETEN.

Skenario kedua yaitu variasi terhadap parameter konsentrasi aktivitas ${ }^{137} \mathrm{Cs}$ untuk mengetahui batas lepasan ${ }^{137} \mathrm{Cs}$ maksimal yang masih aman bagi biota. Simulasi variasi konsentrasi aktivitas ${ }^{137} \mathrm{Cs}$ dilakukan dengan variasi konsentrasi aktivitasnya 50.000 kali, 80.000 kali, 130.000 kali dari konsentrasi aktivitas semula. Hasil simulasinya adalah sebagai berikut.

Tabel 5. Hasil perhitungan dosis dengan variasi konsentrasi aktivitas ${ }^{137} \mathrm{Cs}$

\begin{tabular}{llll}
\hline \multirow{2}{*}{ Biota } & \multicolumn{3}{c}{ Dosis Serap Biota $(\mu \mathrm{G} y / j a m)$} \\
\cline { 2 - 4 } & 50.000 kali & 80.000 kali & 130.000 kali \\
\hline Fitoplankton & 0,03 & 0,05 & 0,09 \\
Zooplankton & 0,02 & 0,04 & 0,06 \\
Crustacea & 88,99 & 142 & 231 \\
Mollusca Gastropoda & 78,90 & 126 & 205 \\
Mollusca Bivalvia & 74,13 & 118 & 192 \\
Amfibi & 2,02 & 3,23 & 5,25 \\
Larva Serangga & 177,46 & 284 & 461 \\
Tumbuhan berpembuluh & 88,52 & 141 & 230 \\
\hline
\end{tabular}

Dari Tabel 5 dapat disimpulkan bahwa konsentrasi aktivitas ${ }^{137} \mathrm{Cs}$ yang terkandung pada sampel sedimen kolam terpadu pada penelitian ini masih aman, karena menghasilkan dosis biota yang masih jauh di bawah batas yang telah ditetapkan. Konsentrasi aktivitas sebesar 50.000 kali dari konsentrasi aktivitas ${ }^{137} \mathrm{Cs}$ awal atau sekitar 55,2 Bq/jam baru mulai menimbulkan potensi bahaya bagi larva serangga (warna kuning). Aktivitas sebesar 130.000 kali dari konsentrasi aktivitas ${ }^{137} \mathrm{Cs}$ awal atau sekitar $121 \mathrm{~Bq} / \mathrm{jam}$ diperkirakan benar-benar berbahaya terutama bagi larva serangga dan menimbulkan potensi bahaya bagi biota lainnya yaitu Crustacea, Mollusca Gastropoda, Mollusca Bivalvia, dan tumbuhan berpembuluh.

Tabel 6. Hasil simulasi variasi debit efluen

\begin{tabular}{llllll}
\hline \multirow{2}{*}{ Biota } & \multicolumn{5}{c}{ Dosis Serap Biota $(\mu \mathrm{Gy} / \mathrm{jam})$} \\
\cline { 2 - 6 } & $1 / 10$ & $1 / 25$ & $1 / 50$ & $1 / 90$ & $1 / 100$ \\
\hline Fitoplankton & 60,27 & 24,09 & 12,04 & 6,69 & 6,03 \\
$\begin{array}{l}\text { Zooplankton } \\
\text { Crustacea }\end{array}$ & 17,06 & 6,82 & 3,41 & 1,90 & 1,71 \\
$\begin{array}{l}\text { Molusca } \\
\text { gastropoda }\end{array}$ & 601,07 & 257,16 & 128,63 & 71,43 & 64,31 \\
$\begin{array}{l}\text { Molusca } \\
\text { bivalvia }\end{array}$ & 557,90 & 240,56 & 120,27 & 66,80 & 60,15 \\
$\begin{array}{l}\text { Amfibi } \\
\text { Larva }\end{array}$ & 60,45 & 24,17 & 12,08 & 6,71 & 6,04 \\
$\begin{array}{l}\text { Serangga } \\
\text { Tumbuhan } \\
\text { berpembuluh }\end{array}$ & $1.217,70$ & 486,95 & 243,57 & 135,25 & 121,77 \\
\hline
\end{tabular}


Pada Tabel 6 terlihat bahwa jika terdapat seluruh radionuklida produk fisi yang berpotensi terlepas dari reaktor riset pada efluendengan konsentrasi aktivitas sama dengan batas yang ditetapkan BAPETEN, maka debit effluent baru benar-benar aman ketika nilainya $1 / 100$ kali dari nilai awalnya yaitu sebesar $0,000162 \mathrm{~m} 3 / \mathrm{jam}$.

Pada simulasi yang terakhir, pada Tabel 7 , dilakukan variasi terhadap jumlah nuklida yang disimulasikan. Variasi dilakukan dengan mempertimbangkan faktor waktu paruh radionuklida. Waktu paruh pada radionuklida mempengaruhi lamanya radionuklida tersebut berada di dalam tubuh makhluk hidup.

Tabel 7. Hasil simulasi dengan variasi jumlah nuklida

\begin{tabular}{llll}
\hline \multirow{2}{*}{ Biota } & \multicolumn{3}{c}{ Dosis Serap Biota $(\mu$ Gy/jam) } \\
\cline { 2 - 4 } & $\begin{array}{l}\text { Kondisi 1 } \\
\text { (24 isotop) }\end{array}$ & $\begin{array}{l}\text { Kondisi 2 } \\
\text { (10isotop) }\end{array}$ & $\begin{array}{l}\text { Kondisi 3 } \\
\text { (3 isotop) }\end{array}$ \\
\hline Fitoplankton & 602,68 & 499 & 319 \\
Zooplankton & 170,62 & 79,3 & 60,9 \\
Crustacea & $6.430,66$ & 479 & 64,92 \\
Mollusca Gastropoda & $6.014,98$ & 814 & 379 \\
Mollusca Bivalvia & $5.578,96$ & 764 & 379 \\
Amfibi & 604,46 & 431 & 261,89 \\
Larva Serangga & 12.177 & 1.030 & 165,78 \\
Tumbuhan berpembuluh & $6.052,74$ & 518 & 117,27 \\
\hline
\end{tabular}

Pada kondisi (1) dari Tabel 7, dilakukan simulasi dengan seluruh radionuklida dengan konsentrasi $100 \%$ dari NBL, yang hasilnya sama dengan simulasi pada skenario pertama pada konsentrasi aktivitas $100 \%$ (Tabel 4). Pada kondisi yang kedua, dilakukan simulasi dengan mengabaikan radionuklida yang memiliki waktu paruh kurang dari satu tahun,sehingga pada kondisi yang kedua dilakukan simulasi dengan radionuklida ${ }^{60} \mathrm{Co},{ }^{125} \mathrm{Sb}$, ${ }^{134} \mathrm{Cs},{ }^{137} \mathrm{Cs},{ }^{90} \mathrm{Sr},{ }^{106} \mathrm{Ru},{ }^{234} \mathrm{U},{ }^{238} \mathrm{Pu},{ }^{239} \mathrm{Pu}$, dan ${ }^{240} \mathrm{Pu}$. Pada kondisi ketiga, dilakukan simulasi dengan mengabaikan radionuklida yang memiliki waktu paruh antara 1-100 tahun, sehingga radionuklida yang disimulasikan adalah ${ }^{234} \mathrm{U},{ }^{239} \mathrm{Pu}$, dan ${ }^{240} \mathrm{Pu}$.

Dari Tabel 7 dapat disimpulkan bahwa pengurangan jumlah nuklida yang terlepas keefluen akan menyebabkan pengurangan terhadap dosis biota secara signifikan (terlihat dari dosis serap yang diterima biota pada kondisi 1 dan kondisi 2). Pada kondisi kedua, pengurangan sebanyak 14 nuklida akan menghasilkan penurunan penerimaan dosis serap dari 604,46 menjadi $431 \mu$ Gy/jam untuk amfibi dan 6430,66 menjadi 479 $\mu$ Gy/jam untuk crustacea $27 \%$ sampai dengan $93 \%$ terhadap dosis serap biota. Pada kondisi 3 , pengurangan hingga sebanyak 21 radionuklida bahkan dapat mengurangi dosis serap biota sampai dengan $99 \%$ pada subfilum Crustacea. Jumlah nuklida merupakan parameter yang paling berpengaruh dibandingkan dengan konsentrasi aktivitas radionuklida dan debit efluen karena variasi pada jumlah nuklida sebenarnya bergantung dengan faktor lainnya seperti karakter radionuklida itu sendiri berupa jenis radiasi yang dipancarkan dan angka $K_{d}$ radionuklida yang berbeda antara satu radionuklida dan yang lainnya.

\section{KESIMPULAN}

Radionuklida yang terkandung pada sampel air adalah ${ }^{212} \mathrm{~Pb},{ }^{214} \mathrm{~Pb},{ }^{228} \mathrm{Ac},{ }^{212} \mathrm{Bi},{ }^{214} \mathrm{Bi}$, dan ${ }^{40} \mathrm{~K}$. Radionuklida yang terkandung pada sampel sedimen adalah ${ }^{228} \mathrm{Ac},{ }^{212} \mathrm{Bi},{ }^{214} \mathrm{Bi},{ }^{212} \mathrm{~Pb},{ }^{214} \mathrm{~Pb}$, dan ${ }^{40} \mathrm{~K}$. Pada kolam pembuangan terpadu terdapat ${ }^{137} \mathrm{Cs}$ dengan konsentrasi aktivitas $1,1 \times 10^{-3} \mathrm{~Bq} / \mathrm{jam}$. Aktivitas ${ }^{137} \mathrm{Cs}$ yang terukur 
masih di bawah batas yang ditetapkan BAPETEN yaitu sebesar $5,1 \times 10^{3} \mathrm{~Bq} / \mathrm{jam}$ dan secara radiologi masih aman bagi biota. Dari tiga parameter yang mempengaruhi penilaian radiologi pada biota yaitu aktivitas radionuklida, debit efluen dan jumlah nuklida, parameter yang paling berpengaruh adalah banyaknya jenis radionuklida. Dosis serap biota dapat digolongkan aman apabila aktivitas radionuklida sebesar $1 \%$ dari batas lepasan yang ditetapkan oleh BAPETEN, atau apabila debit efluen sebesar 1/100 dari angka awal. Pengurangan sebanyak 14 nuklida akan menghasilkan penurunan sebesar $27 \%$ sampai dengan $93 \%$ terhadap dosis serap biota. Pengurangan sampai dengan 21 radionuklida bahkan dapat mengurangi dosis serap biota sampai dengan $99 \%$ pada subfilum Crustacea. Hal tersebut dapat terjadi karena jumlah nuklida juga dipengaruhi oleh faktor lain berupa jenis radiasi yang dipancarkan dan koefisien distribusi radionuklida yang berbeda antara satu radionuklida dan yang lainnya.

\section{UCAPAN TERIMA KASIH}

Terima kasih kepada Departemen Teknik Nuklir dan Teknik Fisika, Fakultas Teknik, Universitas Gadjah Mada dan Pusat Sains dan Teknologi Akselerator BATAN-Yogyakarta atas izin yang diberikan untuk melakukan penelitian ini.

\section{DAFTAR PUSTAKA}

[1]. John R. Cooper, Keith Randle, Ranjeet S. Sokhi, Radioactive Releases in the Environment, Sussex: John Wiley A\& Sons, Ltd, 2002.

[2]. J. E. Brown, B. Alfonso, R. Avila, N. A. Beresford, D. Copplestone, G. Pröhl, A. Ulanovsky, "The ERICA Tool," Journal of Environmental Radioactivity, no. 99, p. 1371, 2008.

[3]. Verve Vetikko, Ritva Saxén, "Application of ERICA Assessment Tool to Freshwater Biota in Finland," Journal of Environmental Radioactivity, no. 101, pp. 82-87, 2009.

[4]. Lorna J. Dallas, Alexandre Devos, Bruno Fievet, Andrew Turner, Brett P. Lyons, Awadhesh N. Jha, "Radiation Dose Estimation for Marine Mussels Following Exposure to Tritium: Best Practice for Use of ERICA Tool in Ecotoxicological Studies," Journal of Environmental Radioactivity, Vols. 155-156, pp. 1-6, 2016.

[5]. D.H. Oughton, G.Stromman, B. Salbu, "Ecological Risk Assessment of Central Asian Mining Sites: application of The ERICA Assessment Tool," Journal of Environmental Radioactivity, no. 123, pp. 90-98, 2013.

[6]. M.D. Wood, W.A. Marshall, N.A. Beresford, S.R. Jones, B.J. Howard, D. Copplestone, R.T. Leah, "Application of The ERICA Integrated Approach to The Drigg Coastal Sand Dunes," Journal of Environmental Radioactivity, no. 99, pp. 1484-495, 2008.

[7]. J. E. Brown, N.A. Beresford, A. Hosseini, "Approaches to providing missing transfer parameter values in the ERICA Tool - How well do they work?," Journal of Environmental Radioactivity 126, p. 399, 2012.

[8]. Sukosrono, "Pengelolaan Air Buangan Terpadu PTAPB-BATAN Yogyakarta," Prosiding Seminar Penelitian dan Pengelolaan Perangkat Nuklir, vol. 1, p. 321, 2009.

[9]. Fei Tuo, Qing Zhang, Qiang Zhou, Cuihua Xu, Jing Zhang, Wenhong Li, Jianfeng Zhang, Xu Su, "Measurement U-238, Ra-228, Ra-226, K-40, dan Cs-137 in Foodstuffs Samples Collected from Coastal Areas of China," Applied Radiation and Isotopes, vol. III, pp. 40-44, 2016.

[10].Gougang Jia, Jing Jia, "Determination of Radium Isotopes in Environmental Samples by Gamma Spectrometry, Liquid Scintillation Counting and Alpha Spectrometry: A Review of Analytical Methodology," Journal of Environmental Radioactivity, vol. 106, pp. 98-119, 2012.

[11].B. Michalic, "NORM contaminated area identification using radionuclides activity concentration pattern in a soil profile," Journal of Environmental Radioactivity, vol. 173, pp. 102-111, 201 